\title{
COLD-AIR TRAP TEMPERATURE RECORDS SUPPORT SIMPLE HIGH-DENSITY AIR-FLOW MECHANISMS AT AN APPALACHIAN LIMESTONE CAVE ENTRANCE SINKHOLE
}

J. Steven Kite

Department of Geology \& Geography, West Virginia University, 330 Brooks Hall, Morgantown, WV, 26506-6300, USA, steve.kite@mail.wvu.edu

John Tudek

Department of Geology \& Geography, West Virginia University, 330 Brooks Hall, Morgantown, WV, 26506-6300, USA, jtudek@mix.wvu.edu

\section{Abstract}

Many Appalachian caves act as cold-air traps, widely open systems chilled by high-density cold air during chilly weather that evolve into density-stratified, nearly closed systems in warm weather. Like algific talus slopes, rock cities, and other cold-air traps in the region, these caves appear to function in accordance with a simple natural refrigeration model popularized by Balch (1900), in which circulation is dominated by static, thermally stratified conditions episodically disrupted by sinking cold air. Crowder Cave, in Monroe County, West Virginia, hosts two separate cold-air traps, a small room and a large room, both contiguous to an entrance pit, a $\sim 12,000 \mathrm{~m}^{3}$ sinkhole surrounded by 6 to $18 \mathrm{~m}$ high limestone cliffs. The sinkhole and both cave rooms are poorly connected to surface runoff and subsurface water flow. Davies (1958) reported historical accounts of seasonal ice in the small room as late as July, but our temperature monitoring indicates ice regularly has disappeared by late April in five of the last six years. The entrance pit functions as a relatively open cold-air trap system with a mean annual temperature of $\sim 7^{\circ} \mathrm{C}$, well below mean annual air temperatures of $\sim 10^{\circ} \mathrm{C}$ recorded at nearby weather stations. In summer, both cave rooms are virtually closed systems with gradual $\left(<0.1\right.$ to $0.2 \mathrm{C}^{\circ} /$ day) temperature increases; neither had a reading $>9.2^{\circ} \mathrm{C}$ during our monitoring. In stark contrast, both rooms often experience winter episodes of rapidly plunging ( 4 to $8 \mathrm{C} /$ day) temperatures, dipping as low as -13 to $-15^{\circ} \mathrm{C}$. Icicles, columns, frozen lenses, and other ice accumulations have been observed in the small $\sim 350 \mathrm{~m}^{3}$ room at the northeast end of the cave, where five-year mean temperature was $\sim 2.6^{\circ} \mathrm{C}$. Ice stalagmites and other ice forms have been seen on the floor of the large $\sim 12,000 \mathrm{~m}^{3}$ room on the south end of the pit, where the mean temperature was $\sim 3.4^{\circ} \mathrm{C}$.
Entrance pit temperatures respond very quickly when atmospheric conditions are appreciably colder than existing air in Crowder Cave; temperature trends in the two rooms seldom lag more than 1-3 hours behind. Despite similar timing, the amplitude of temperature response in the large room is markedly less than in the small room, presumably because of a 35-fold difference in room volume. The amplitude of temperature change decreases and mean temperature increases with distance from the mouth of the large room. More characteristic of typical cave conditions, temperatures near the end of a narrow $85 \mathrm{~m}$ long side passage varied little $\left(9.8^{\circ}\right.$ to $10.6^{\circ} \mathrm{C}$ ) over the last 4.5 years. Crowder Cave data show the interplay between density-driven cold-air flow, karst topography, and cave geometry lead to variability in winter conditions that may give rise to very different bat hibernacula conditions in a single cave. The ecological significance of cold air traps associated with sinkholes may be profound, both as climate change indicators and for a potential role they may play in the course of the ongoing white-nose syndrome (Pseudogymnoascus destructans) epidemic.

\section{Introduction}

Edwin Swift Balch (1897, 1900) introduced the phenomenon of freezing caverns, or glacières naturelles, to the American speleological community, describing examples of caves he observed in Europe and over a dozen freezing sites in the Northeastern United States and Iowa. Although most of Balch's American sites were "freezing talus", his discussion of a freezing mechanism focused on caves (Balch, 1900). After dispelling other proposed mechanisms, he championed "The Winter's Cold Theory" in which "cold air of winter sinks into and permeates the cave" leading to the formation of ice, which, sheltered from summer heat by the cave, long 
outlasts ice in the surrounding landscape. Balch (1900) continued "The only effect of the heat of summer is to melt the ice."

Balch (1900) noted that other scholars had put forth similar mechanisms for cold air traps as early as the 16th Century. An intriguing forerunner was C.B. Hayden (1841, 1843), who advocated a similar model for ice formation in Ice Mountain talus, Hampshire County, West Virginia. Hayden explained the Ice Mountain freezing mechanics as the "familiar principle upon which is constructed the common refrigerator", enhanced by poor thermal conduction properties of the sandstone talus.

Balch $(1897,1900)$ differentiated between static freezing caves, dominated by thermal stratification of cold air, and dynamic cold-current caves, a.k.a. wind-holes, from which dense cold air pours out in the summer, followed by a reversed flow of cold air drawn into the cave because of chimney effects during the winter. Balch recognized "wind-holes do not seem to necessitate the presence of ice", and thus, they were not considered freezing caves.

Studies of freezing caves continued after Balch, but discovery of a "living fossil", the Iowa Pleistocene Snail (Discus macclintoki), drew attention to the ecological significance of freezing talus and freezing caves (Frest, 1981, 1991). The snail was known from Pleistocene deposits in the Midwest, but Frest (1981) recognized living Discus macclintoki and other cold-adapted plant and animal species survived in relict boreal refugia on cold-air producing hillslopes, which Frest named algific talus slopes. Frest (1991) documented $>300$ sites in
Iowa, Wisconsin, Illinois, and Minnesota, and noted they occur where talus accumulations cover glacières created by "mechanical karst" developed on carbonate bedrock last glaciated $>130,000$ years ago. Frest $(1981,1991)$ championed an algific talus circulation model similar to the dynamic two-way flow system Balch (1900) proposed for wind-holes, wherein the partial vacuum created by a chimney effect is responsible for drawing cold air into the slope during winter.

A long-term goal of our research has been to assess whether Central Appalachian cold-air traps follow the largely one-way static cave/natural refrigerator airflow model of Hayden (1843) and Balch (1900) or the seasonal two-way model favored by Frest (1981). Studies (Edenborn et al., 2012; Kite and Tudek, 2014, 2017) show static thermal stratification by cold air density best explains low temperatures and ice formations at several Appalachian talus and an ice mine site in Pennsylvania. The main goal of this study is to examine which airflow model best applies to Central Appalachian freezing caves, specifically a relatively simple limestone cave system with a large open sinkhole entrance.

\section{Crowder Cave}

Crowder Cave (Figure 1) is a periodically freezing cave with two separate cold air-trapping rooms connected to a single $\sim 12,000 \mathrm{~m}^{3}$ sinkhole in Monroe County, West Virginia (Balfour, 2011). Davies (1958) reported: "Ice has been collected by local residents as late as July" in the small room, but we saw no ice in visits on 9 July 2016 or 8 July 2017. We saw substantial ice in both rooms during visits on 8 January 2013 and 24 February 2014, a few melting ice accumulations in both rooms on

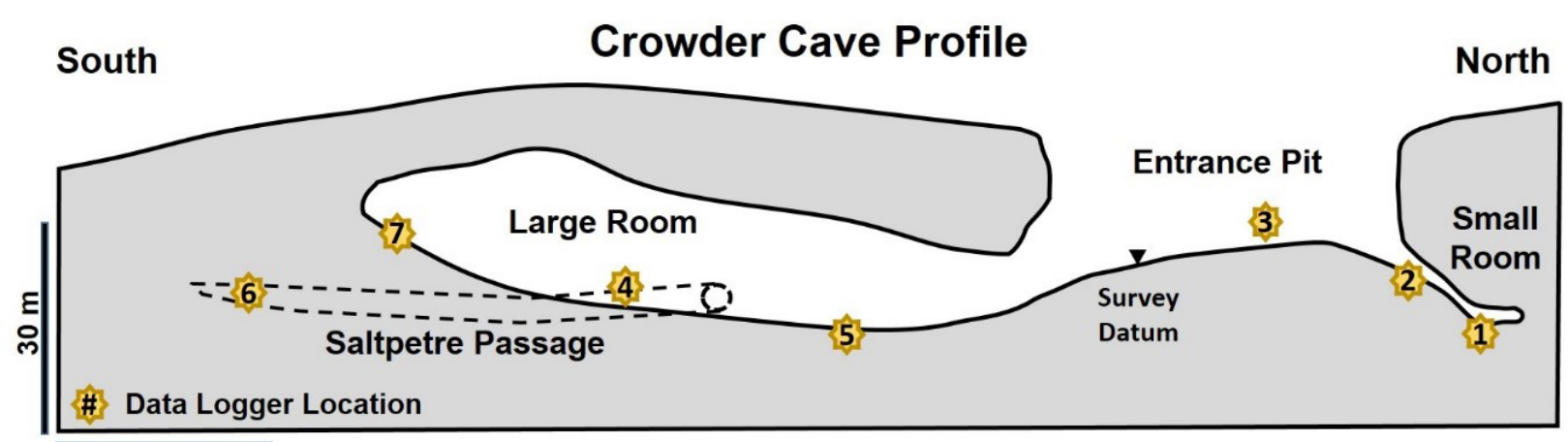

$30 \mathrm{~m}$

Figure 1. Crowder Cave profile showing data logger locations. Saltpetre Passage connects to large room, but aligned 30 to 90 degrees east of profile line. Cave profile is from Balfour (2011) elevation and ceiling height data; surface topography is based on Google Earth elevations. 
25 April 2015, and tiny ice stalagmites in the small room on 13 November 2011. The upper rim of the sinkhole lies at about $632-633 \mathrm{~m}(\sim 2075 \mathrm{ft})$ altitude, on a hillcrest $\sim 100 \mathrm{~m}(330 \mathrm{ft})$ above Second Creek, the nearest perennial stream.

The cave lies in the lower Mississippian Greenbrier Group, but which subunit is uncertain. Davies (1958) reported the cave is developed at the top of the Patton Limestone, but Ogden (1976) mapped it at the contact between the Patton and the underlying Sinks Grove Limestone. Cherty layers in lower levels of the cave are typical of the Sinks Grove (White, 2018) suggesting cliffs that form the walls of the sinkhole and the ceiling of the cave may be in the lower Patton Limestone, whereas lower parts of the cave extend down into the upper Sinks Grove.

Limestone cliffs around the sinkhole perimeter vary from 6 to $18 \mathrm{~m}$ high. The sinkhole floor is covered by breakdown that slopes in opposing directions toward the two rooms. Extending northeast of the sinkhole, the small room has a volume of $\sim 350 \mathrm{~m}^{3}$, while the large room southwest of the sinkhole has a volume of $12,000 \mathrm{~m}^{3}$ (Figure 2). The small room has a relatively flat floor that terminates in a $2 \mathrm{~m}$ high bedrock wall; the southern end of the large room rises to elevations higher than most of the entrance pit floor (Figure 1).

The $\sim 1,000 \mathrm{~m}^{3}$ Saltpetre Passage runs $\sim 85 \mathrm{~m}$ south from the large room, but the two rooms have no other substantial side passages (Balfour, 2011). No active stream channels are evident anywhere in the cave, although woody debris suggests occasional ponding at

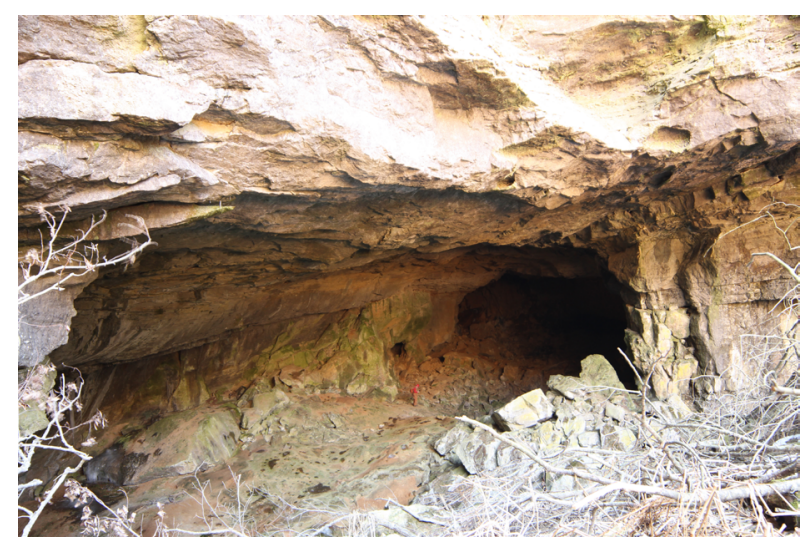

Figure 2. Eight to $12 \mathrm{~m}$ high entrance to the large room, viewed from the sinkhole entrance pit. J. Tudek Photo the lowest points in the two rooms. The most abundant cave sediment is breakdown, including fallen and toppled speleothems; intact speleothems are abundant in the small room. A dissected accumulation of oxidized chert-rich cobble-pebble gravel near the back of the large room show stream flow was once active within cave, but this through-flowing drainage system has been long-abandoned.

Both rooms are well connected to the atmosphere via the sinkhole entrance pit, but receive water largely through downward vadose flow through over-lying roof rock, with lesser influx near their entrances via indirect runoff from the sinkhole, ice fall and ice melt from the cliff faces, or drifting snow and errant precipitation. Compared to most caves in the region, the hydrology and thermal energy flux in Crowder Cave is only very weakly connected to groundwater.

\section{Methods}

Onset Computers Hobo Pendant 64 kb (UA-001 and UA-002) temperature loggers were installed in seven different Crowder Cave locations (Figure 1), based on local caver guidance, Davies's (1958) cave description, and field observations. Loggers were deployed on seemingly stable surfaces, wired to a fist-sized angular rock fragment to avoid displacement, flotation, or pilfering by caching animals, hidden from plain view to elude discovery by curious cavers. Measurement interval was 60 minutes. UA-002 light intensity data yielded little insight besides non-stop 0.0 readings at five sites.

Temperature loggers were installed at locations 1 through 5 on 11 November 2011. Initial deployment was planned to collect data from the entrance pit sinkhole (location 3) and locations very near the lowest points in the two cave rooms (locations 1 and 5). Location 2 was picked to assess air entering the small room, while location 4 was selected to assess temperatures a few meters above the floor, well away from the large room entrance. An on-site surface weather station was deemed unfeasible because of intense cattle grazing and unchaperoned recreational caving. Anomalous temperature readings led to two new logger deployments: location 6, near the back of the narrow, $85 \mathrm{~m}$ long Saltpetre Passage, on 8 January 2013; and location 7, at the highest readily accessible stable surface in the large room, on 24 February 2014. 
All data loggers were most recently downloaded on 18 July 2017, except for a logger at location 3, last downloaded on 25 April 2015, which was inaccessible during our last two visits because of a downed tree. Location 2 was abandoned in July 2017 because of instability on its steep slope, but loggers are deployed at the other six Crowder Cave locations, adding to $>350,000$ temperature measurements made so far.

Loggers were exchanged at each deployment to avoid potential malfunctions inherent in optically down-loading data and servicing loggers in the cave environment. Loggers were later downloaded and serviced in an office environment. One logger at location 7 failed for $>9.5$ months, but records are otherwise continuous except for 1 to 2 hour periods of equilibration after each deployment for which anomalous readings were excluded from analysis. Manufacturer's data show measurements are accurate to $+0.7 \mathrm{C}^{\circ}$, with resolution of $<0.2 \mathrm{C}^{\circ}$ over the temperatures seen in the cave. Time is accurate to +1 minutes/month. Lab calibration experiments show some loggers regularly read a few tenths of a $\mathrm{C}^{\circ}$ above or below others, so our protocol of switching loggers with each deployment adds to potential measurement inaccuracy. Differences between locations of $<1 \mathrm{C}^{\circ}$ may not be significant. Logger contact with rock surfaces may delay or reduce response to short-lived cold-air incursions, but probably by similar amounts for all of the similarly deployed loggers. Hence, we contend our data provide informative records of the timing and magnitude of responses to the thermal phenomena in the entrance pit sinkhole and Crowder Cave.

\section{Site-to-Site Temperature Variations}

The Crowder Cave temperature record (Figure 3, Table 1) is complex. Site to site variation is apparent, but partly obscured by seasonal trends aligned with (October to September) water-year cycles). Most locations responded quickly and similarly during autumn and winter, but much more gradually and disparately during spring and summer. The small room (location 1) and large room floor (location 4) are the coldest locations, with mean temperatures and standard deviations of $2.6^{\circ} \mathrm{C}+3.2 \mathrm{C}^{\circ}$ and $3.1^{\circ} \mathrm{C}+3.8 \mathrm{C}^{\circ}$, respectively. Neither

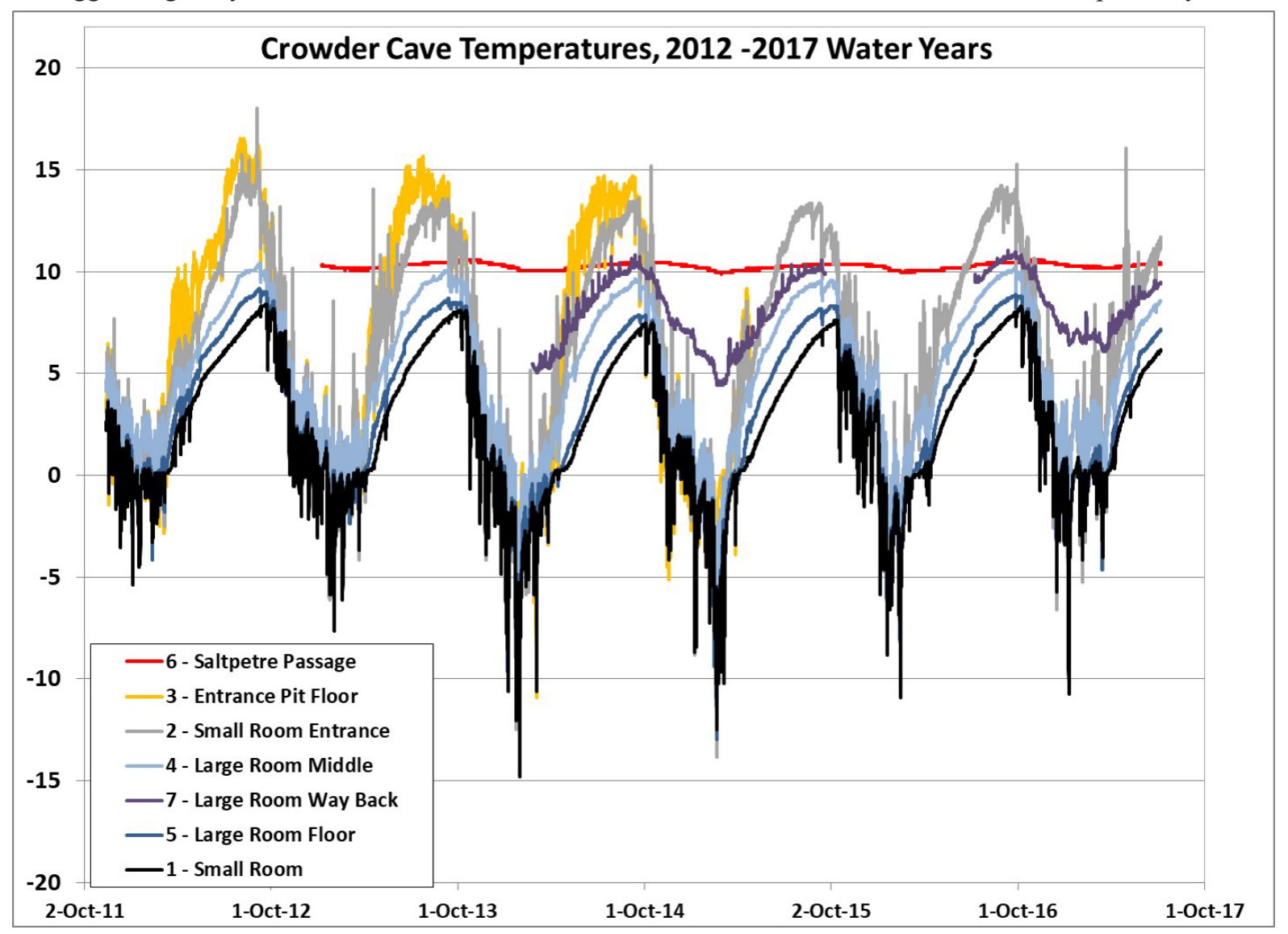

Figure 3. Crowder Cave temperatures, November 2011 to July 2017. Records at four locations are continuous over the period, but locations 3,6 , and 7 are less complete. 


\begin{tabular}{|l|c|c|c|c|}
\hline & \multicolumn{4}{|c|}{ Temperatures ${ }^{\circ} \mathrm{C}$} \\
\hline Location \# & Mean & Max & Min & StDev \\
\hline Small Room 1 & 2.6 & 8.4 & -14.8 & 3.58 \\
\hline Small Rm Entr. 2 & 6.2 & 18.0 & -14.5 & 5.22 \\
\hline Sinkhole Floor 3 & 6.2 & 16.5 & -14.6 & 5.94 \\
\hline Large Rm Floor 5 & 3.1 & 9.2 & -13.0 & 3.84 \\
\hline Large Rm Mid 4 & 5.0 & 10.5 & -9.1 & 3.56 \\
\hline Large Rm Back 7 & 8.1 & 11.0 & 4.4 & 1.69 \\
\hline Saltpetre Passage 6 & 10.3 & 10.6 & 9.9 & 0.15 \\
\hline
\end{tabular}

Table 1. Crowder Cave summary statistics. Location numbers match Figures 1 and 3.

site experienced a reading $>9.2^{\circ} \mathrm{C}$, remaining below the $10.0^{\circ} \mathrm{C}$ mean annual temperature at a nearby Lewisburg NOAA weather station during every hour for $\sim 5.7$ years. (The Lewisburg station lies only $21 \mathrm{~km}$ north-northeast of, and about $\sim 62 \mathrm{~m}$ higher than, Crowder Cave.) The entrance pit floor and small room entrance rose above $10^{\circ} \mathrm{C}$ for prolonged periods in late spring and summer and infrequently recorded temperatures $>15^{\circ} \mathrm{C}$ during warm rainfall, but both had long-term mean temperatures of only $6.2^{\circ} \mathrm{C}$. Variability decreases and mean temperatures increase in the large room with distance from the entrance. The remote Saltpetre Passage recorded a mean of $10.3^{\circ} \mathrm{C}+0.15 \mathrm{C}^{\circ}$. Measurements ranged only from $9.8^{\circ}$ to $10.6^{\circ} \mathrm{C}$ during the last 4.5 years, a pattern more typical of local caves.

The two colder locations lie in roof-sheltered, lowlying sites near a cave entrance adjacent to the entrance pit sinkhole. Although the sinkhole and small room entrance experienced similar minimum temperatures, they are higher on the landscape and much more exposed to wind, sun, and precipitation; thus, these exposed locations recorded temperatures approaching - but not reaching - ambient warm weather conditions. Data show the sinkhole acted as a discernable cold-air trap, but one more open and less stable than nearby low-lying cave locations.

\section{Seasonal and Annual Variations}

Data from the warmest and coldest years in our record for the small room and the large room floor (Figure 4) reveal the mechanics of these two cold-air traps,

Crowder Cave: Small Room vs. Large Room: 2012 \& 2014 Water Years

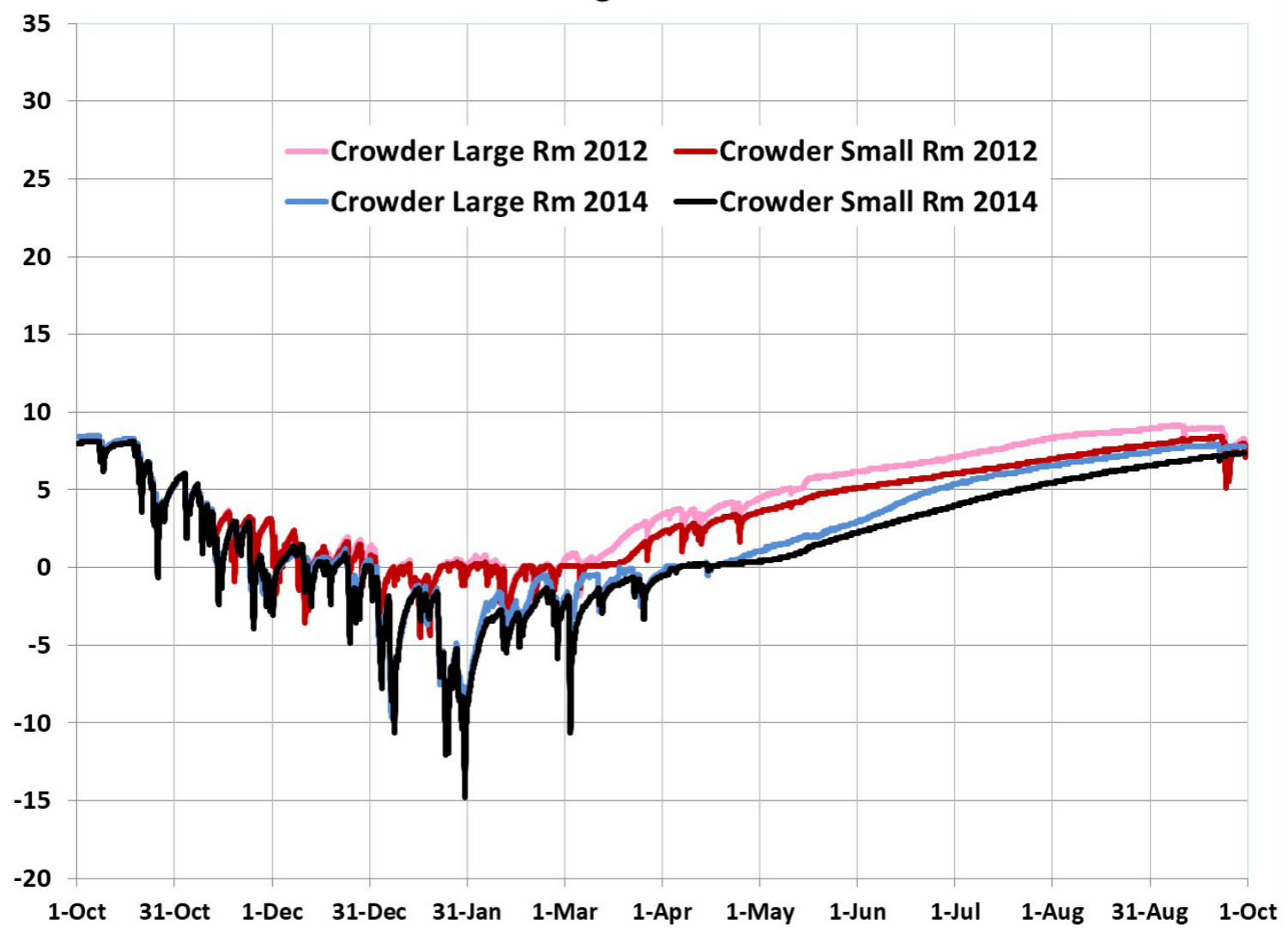

Figure 4. Temperatures at the two coldest Crowder Cave locations in an exceptionally warm early melt-out year (2012) and a colder late melt-out year (2014). 
including ways these mechanics vary from season to season, year to year, and location to location. The timing of day-to-day fluctuations aligned well, but differences between the two locations were apparent both years. Each water year commenced with generally falling temperatures punctuated by sharp declines of up to $5 \mathrm{C}^{\circ}$ when cold outside temperatures triggered dense air flows into the cave entrances. Air circulation was an open system for much of this period, which continued well into both winters.

During the warmest year, 2012, winter minimum temperatures were nearly $10 \mathrm{C}^{\circ}$ above those of the coldest year, 2014, and very few cold snaps occurred after mid-January. Temperatures at the small room and large room floor locations hovered near $0^{\circ} \mathrm{C}$ for most of winter 2012, suggesting an unknown amount of ice moderated temperatures. An unprecedented heat wave began 1 March 2012 (Borth et al., 2012) and the large room floor temperatures began to rise immediately, but slowly, interrupted by very brief incursions of cool air over the next eight weeks.

The immediate warming of the large room coincident with warm weather suggests winter ice in the large room had already melted. The small room held $\sim 0^{\circ} \mathrm{C}$ temperatures until $\sim 20$ March, when, apparently depleted of winter ice, it began an unusually early temperature climb. The next two months saw temperature rises of $\sim 0.1 \mathrm{C} /$ day, which decreased to $\sim 0.03 \mathrm{C} \%$ day after 15 May. Both rooms remained closed stratified systems until cool air incursions near the end of the 2012 water year in September.

In the colder 2014 winter, both rooms were generally open systems, dropping to $-15^{\circ} \mathrm{C}$ in late January and $-11^{\circ} \mathrm{C}$ in early March. Our 24 February 2014 visit revealed significant ice in various forms in the small room (Figure 5) and numerous melting ice stalagmites in the large room (Figure 6). Icicles in the large room clustered on low ceiling near the entrance pit, while most ice stalagmites formed below unfrozen high-ceiling drip sources, $>10 \mathrm{~m}$ above the floor.

Verifying IR temperature data and sensory perception during our visit, stabilized logger data two hours later showed location 7 was $6.0 \mathrm{C}^{\circ}$ warmer than location 5 . A $4.4^{\circ} \mathrm{C}$ minimum temperature shows location 7 , far back in the cave and $16.5 \mathrm{~m}$ above the low point in the room, never froze. With temperatures 2 to $18 \mathrm{C}^{\circ}$ warmer at location 7 than at location 5 during 2.5 years of overlapping data, thermal stratification in the large room was incessant. Substantial ice in the cave probably helped maintain low temperatures later than usual during 2014. The large room floor rose above $0^{\circ} \mathrm{C}$ and began to increase significantly around 15 April, while a similar rise occurred about three weeks later in the small room, despite the latter's sunnier aspect. Thereafter, the two systems remained a thermally stratified, nearly closed system with an average rise of $<0.05^{\circ} \mathrm{C} /$ day.

Relative to the large room, its delayed rise above $0^{\circ} \mathrm{C}$ during all years of record suggests the small room is a more effective cold-air trap, or its ice persistence is more dominant in its seasonal thermal progression. These two explanations are not mutually exclusive.

\section{Short-Term Temperature Variations}

Two four-day late-winter temperature plots (Figures 7 and 8) show how temperatures at cave locations respond to short-term outside temperature declines. A March 2014

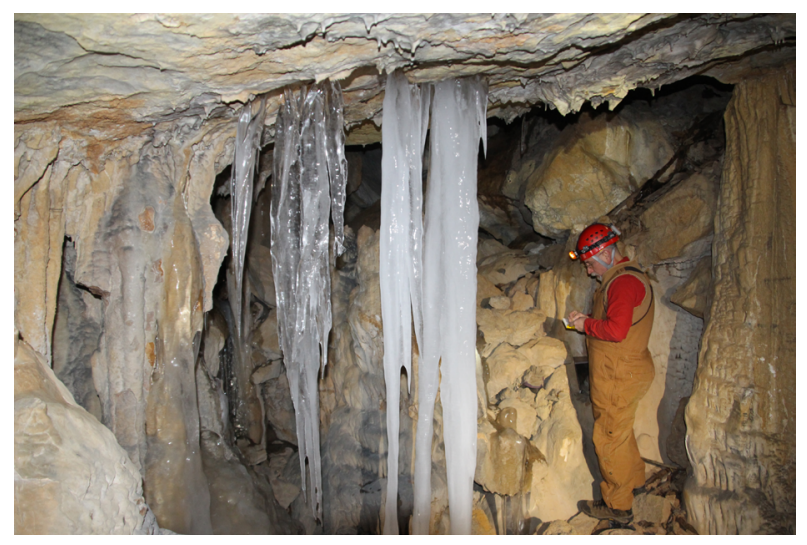

Figure 5. Icicles and other ice growths in the Crowder Cave small room. J. Tudek photo.

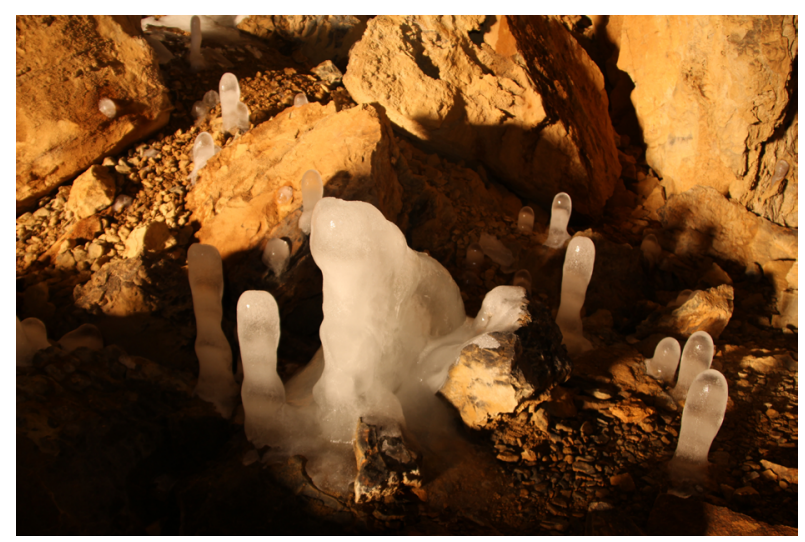

Figure 6. Ice stalagmites in the large room. J. Tudek photo. 
cold front triggered a straight-forward cave temperature response (Figure 7). Lewisburg NOAA data show a $12^{\circ} \mathrm{C}$ high temperature on $3 \mathrm{March}$, falling to $-20^{\circ} \mathrm{C}$ on 4 March and $-16.7^{\circ} \mathrm{C}$ on 5 March. No snow cover was reported until $5 \mathrm{~cm}$ fell on $3 \mathrm{March}$, growing to a $10 \mathrm{~cm}$ cover for the next two days. Six of seven Crowder Cave locations had temperature declines between 16:00 EST 3 March and 09:00 EST 4 March. Magnitude of change varied widely, but timing was similar at all locations. The open sites, the entrance pit and small room entrance, fell 11.1 and $9.5 \mathrm{C}^{\circ}$, respectively, with daily minima 1 to 3 hours before other sites. Though temperatures at the two best cold-air trap locations were both $-2^{\circ} \mathrm{C}$ on the afternoon of the $3 \mathrm{rd}$, location 1 in the small room dropped $8.8 \mathrm{C}^{\circ}$ in the next 13 hours, outpacing location 5 on the large room floor, which declined only $5.7 \mathrm{C}^{\circ}$ to reach an event minimum an hour later. Farther from the big room entrance and slightly above the floor, location 4 began the period at $+2 \mathrm{C}^{\circ}$ but dropped a similar $5.8 \mathrm{C}^{\circ}$ at nearly the same time as the lowest point in the big room. By 12:00 on the 4 th, temperatures at locations 4 and 5 were almost identical, and remained so for the next 24 hours. This equilibration suggests mixing of newly introduced air. Location 7, far back from the entrance and near the top of the large room had a mere $0.2 \mathrm{C}^{\circ} \mathrm{dip}$, but it occurred simultaneously with large temperature declines in parts of the cave directly linked to the atmosphere. Meanwhile, the remote Saltpetre Passage appeared unaffected by this cold front.

Modest cave temperature shifts occurred 5 March 2014, despite the fact that low outside temperatures at Lewisburg were $>10 \mathrm{C}^{\circ}$ colder than any location in Crowder Cave. We are unsure why this was the case.

A succession of cold fronts led to a prolonged cold spell between 16 and 22 February 2014, with Lewisburg low temperatures reaching $-17^{\circ} \mathrm{C}$ on the $18 \mathrm{th},-20^{\circ} \mathrm{C}$ on the 19 th, and $-22^{\circ} \mathrm{C}$ on the 20 th, a date when the high was only $-17^{\circ} \mathrm{C}$. A $23 \mathrm{~cm}$ snowfall on the 17 th led to snow depths ranging from 20 to $23 \mathrm{~cm}$ over the period. Cold antecedent conditions meant this four-day period began

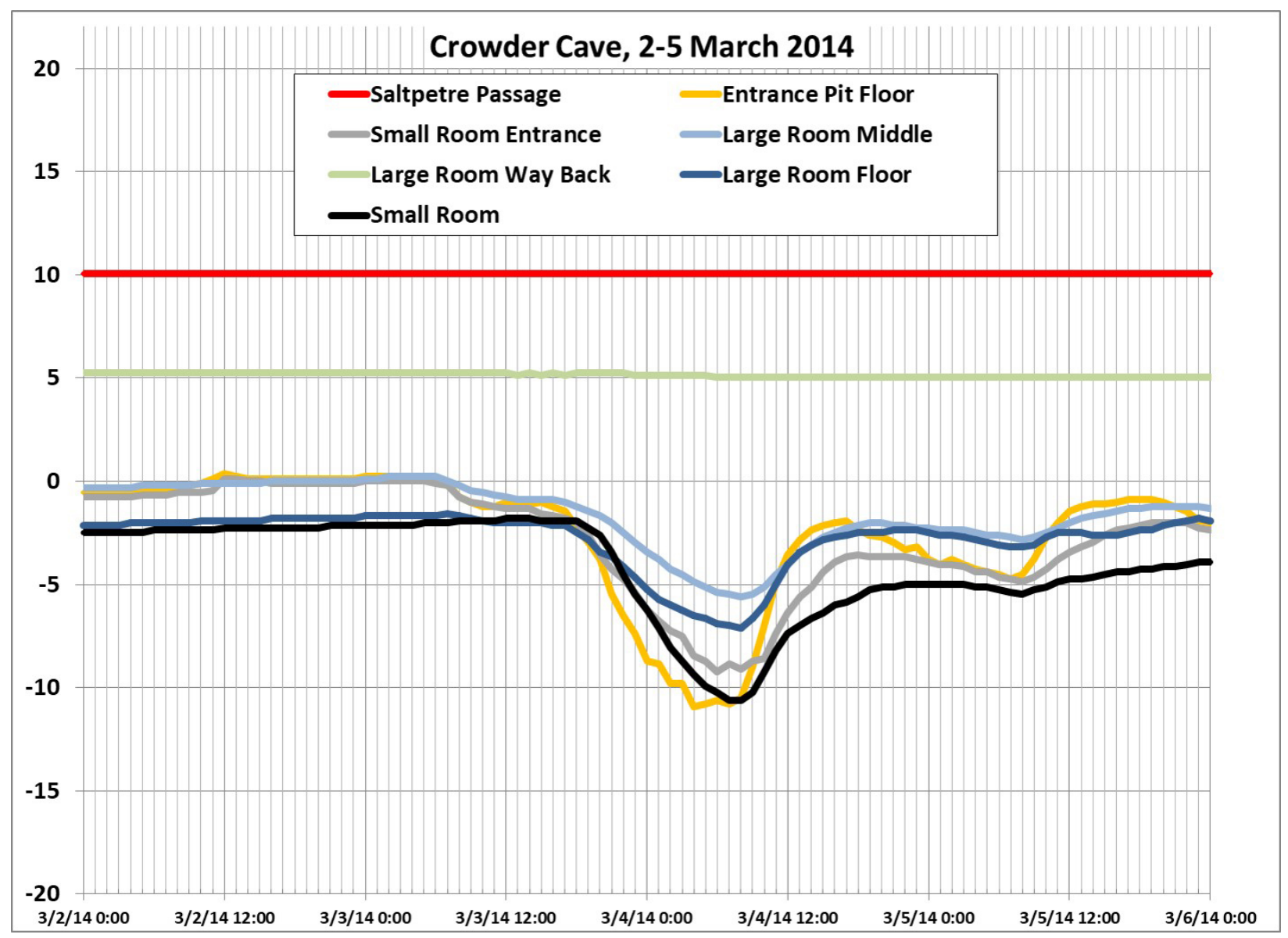

Figure 7. Crowder Cave response to two consecutive nights with unusually cold temperatures. 


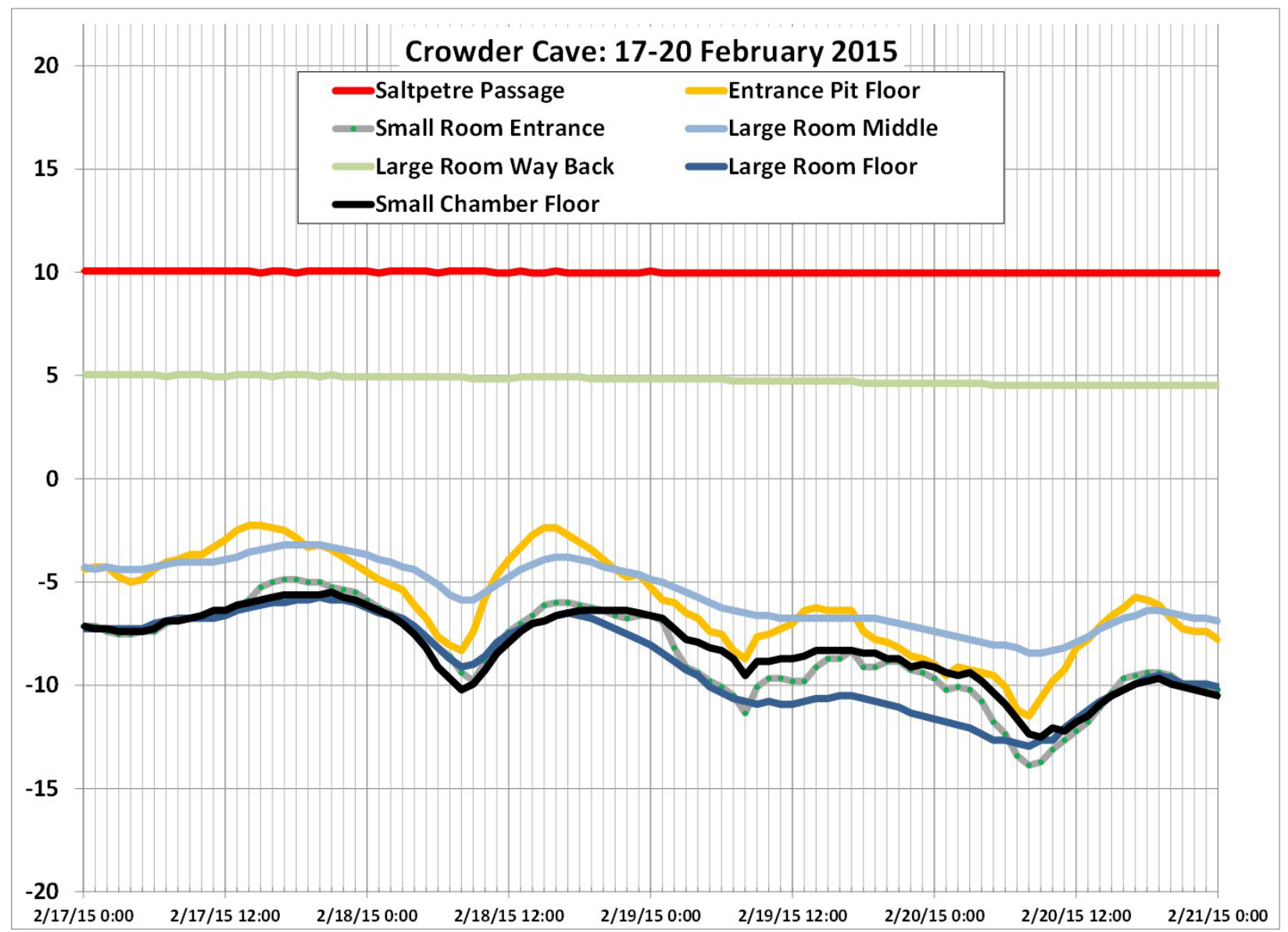

Figure 8. Crowder Cave response to a prolonged cold spell when highs did not exceed freezing.

with most of the cave about $5 \mathrm{C}^{\circ}$ colder than the March 2015 event, decreasing the potential for heat exchange from cave surfaces and sediments to fuel diurnal temperature rebounds.

The snow cover may have insulated the data logger in the unsheltered entrance pit from the coldest early morning conditions. The sinkhole experienced a $9.7 \mathrm{C}^{\circ}$ decline, but unlike most cold snaps, this location was warmer than three other locations for the entire fourday period. The small room entrance and the small room declined 9.0 and $7.0 \mathrm{C}^{\circ}$ over the period, vacillating in relatively similar patterns, which were more erratic than the locations in the large room. Location 5 temperatures declined only $6.6 \mathrm{C}^{\circ}$, but were lower than the other sites for almost all of a 38 hour period, at times nearly $3 \mathrm{C}^{\circ}$ below that of the ordinarily colder small room. Unlike the March 2015 event, locations 4 and 5 temperatures had almost no convergence, suggesting strong thermal stratification and little mixing of air throughout the room. The thermal stratification increased as the outside temperature hovered near $-20^{\circ} \mathrm{C}$ on February 20 th. Back in the cave, near the top of the large room, location 7 saw a $0.5 \mathrm{C}^{\circ}$ decline over 57 hours, while the normally constant temperature in Saltpetre Passage fell 0.1 C .

\section{Discussion}

Crowder Cave is an example of a freezing cavern, or glacière naturelles, as described by Balch (1897, 1900). Its two chambers are connected by a sinkhole that acts as a cold air trap in its own right. The redundancy of the 15-18 m deep entrance pit sinkhole to provide significant shelter to the two cave entrances and serve as a first chamber for cold-air density stratification may explain why the thermal behavior of Crowder Cave differs so remarkably from most other caves in the region.

Cave temperatures, viewed over various timescales, point to density-driven cold-air flow into the cave as the key mechanism leading to cold temperatures and the formation of ice in the two Crowder Cave rooms. Shelter provided by the cave favors the persistence of thermal 
stratification through subsequent warm atmospheric conditions, allowing the air to warm slowly and ice to last into warm weather. Continuous above-freezing conditions at upper levels of the large room show there is no seasonal chimney effect operating to draw cold air into the room entrance. Crowder Cave temperature data are consistent with the natural refrigeration model proposed by Hayden $(1841,1843)$ and the compatible Winter's Cold Theory widely articulated by Balch (1897, 1900).

The two four-day winter cold episodes (Figure 7 and 8) reveal that the two rooms act somewhat differently in spite of a similar refrigeration mechanism. The differences relate to chamber volume and the heatsink role that ice provides in maintaining cold air. Although its opening to the sinkhole is smaller, the small room's $\sim 350 \mathrm{~m}^{3}$ volume is more quickly filled by cold-air density currents during a cold episode. The ceiling in the room is only $2-3 \mathrm{~m}$ high, providing too little vertical space for distinct thermal stratification, so ice can form anywhere in the room once cold conditions are established. No space in the room is $>25 \mathrm{~m}$ from the entrance, so there are opportunities for drifting snow or freezing rain to enter the chamber. A substantial fraction of the room may be occupied by ice during winter, and this ice may persist in the shelter of the cave for weeks or months after warm weather onset. The greatest limitation on the small room functioning as a freezing cave is that deep snow or seasonal ice buildup may partly block the flow of cold air into the room.

The huge large room entrance would be virtually impossible to block with snow and ice under any climate likely to have existed in the region since the end of the Younger Dryas, 11,500 years ago. The $12,000 \mathrm{~m}^{3}$ volume, considerable length and shape of the large room makes it very difficult to fill with cold air during a brief cold spell, although the February 2014 data show longer events effectively mantle lower portions of this room with very cold air. The 15 to $22 \mathrm{~m}$ ceiling heights, which rise well above the top of the cave entrance, provides an excellent chamber for density-driven thermal stratification, and make it very unlikely for ice to form on high surfaces in the room. Proportional to volume, there will always be less ice in the large room, providing less of a latent heat sink to maintain ice into warmer seasons.

\section{Insights into Changing Cave Ecosystems} Davies's (1958) statement that ice has been collected from the small room as late as July contrasts with our July field observations and temperature records showing melt out typically occurs by late April. It is uncertain whether folklore about late-persisting ice reflects low winter temperatures, delayed seasonal warming, high snowfall, high winter precipitation, human ice management, or possible imprecise memory. Dated historical temperature measurements, photographs, and ice observations recorded in diaries or field notes may provide insights into whether or not Crowder Cave and other Appalachian freezing caves serve as bellwethers of changing climate.

Traditions of ice lasting much longer in the historical past compared to recent decades exist at many wellknown freezing caves in the Central Appalachians. At face value, these traditions could be evidence of climate warming in the region (US Environmental Protection Agency, 1998). Although concerns exist over their scientific rigor, the abundance and wide geographic distribution of these accounts suggest there is something of substance to these traditions.

The ecological consequences of a reduction in the persistence of cave ice or the complete disappearance of freezing caverns would be unfortunate. Atypically cold caves may be refugia for relicts of Pleistocene ecosystems, similar to the manner in which some algific talus slopes provide refugia for boreal flora and fauna (Frest, 1991; Lendemer et al., 2009). The density current and thermal stratification processes that lead to freezing caves may be highly important in numerous cave passages that are atypically cold, but not to the point of freezing. Such caves may provide temperature diversity in bat hibernacula, which may enhance conditions favorable to a variety of species, some of which have seen drastic declines from the ongoing white-nose syndrome (Pseudogymnoascus destructans) epidemic (Perry, 2013). White-nose syndrome isolates grow between 5 and $20^{\circ} \mathrm{C}$, growing optimally at $12-13^{\circ} \mathrm{C}$ (Perry, 2013), so atypically cold caves may provide hibernacula in which some bat species may avoid extirpation and stage a recovery.

\section{References}

Balch ES. 1897. Ice Caves and the causes of subterranean ice. Journal of the Franklin Institute. CXLIII (3) 161-178. 
Balch ES. 1900. Glacières or freezing caverns. Philadelphia, PA: Allen, Lane and Scott.

Balfour B. 2011. Crowder Cave Monroe County, West Virginia: WV Association for Cave Studies 2010 Map. West Virginia Caver, 29 (1) appx.

Borth S, Castro R, Birk K. 2012. The Historic March 2012 Heat Wave: A Meteorological Retrospective (website viewed 25 September 2017) https://www. weather.gov/media/lot/events/March2012/March_ Heatwave_2012_final.pdf.

Davies WE. 1958. Caverns of West Virginia. West Virginia Geological and Economic Survey Volume 19A, 402 p.

Edenborn HM, Sams JI, Kite JS. 2012. Thermal regime of a cold air trap in Central Pennsylvania, USA: the Trough Creek Ice Mine. Permafrost and Periglacial Processes, 23(3): 187-195.

Frest TJ. 1981. Project SE-1-2 Iowa Pleistocene Snail Final Report May, 1980-January, 1981. Iowa City (IA): Dept. of Geology University of Iowa.

Frest TJ. 1991. Summary status reports on eight species of candidate land snails from the Driftless Area (Paleozoic plateau), upper Midwest. Seattle (WA) Final report submitted to the U.S. Fish and Wildlife Service, Region 3.

Hayden CB. 1841. Ice Mountain of Hampshire County, Virginia. Farmers' Register 9 (3): 151.

Hayden CB. 1843. On the Ice Mountain of Hampshire County, Virginia, with a proposed explanation of its low temperature. The American Journal of Science and Arts 45: 78-83.

Kite JS, Tudek J. 2014. Cold-air trapping cave passages and algific talus slopes in the Central Appalachians: similar thermal regimes point to similar Balch refrigeration mechanism. Geological Society of America Abstracts with Programs 46 (6): 393.

Kite JS, Tudek J. 2017. Many similarities and some noteworthy differences in cold-air trapping mechanisms at algific talus slopes, rock cities, and cave passages in the Central Appalachians. Geological Society of America Abstracts with Programs 49, (6).

Lendemer JC, Edenborn HM, Harris RC. 2009. Contributions to the lichen flora of Pennsylvania: Notes on the lichens of a remarkable talus slope in Huntingdon County, Pennsylvania. Opuscula Philolichenum 6: 125-136.

Ogden AE. 1976. The hydrogeology of the central Monroe County karst, West Virginia [Ph.D. Dissertation] Morgantown, (WV): West Virginia University. 263 p.
Perry RW. 2013. A review of factors affecting cave climates for hibernating bats in temperate North America. Environmental Reviews 21(1): 28-39.

US Environmental Protection Agency. 1998. Climate Change and West Virginia. EPA 236- F-98-007cc. $4 \mathrm{p}$.

White WB. 2018. Geology of the Greenbrier Valley. In White WB, ed. Caves and Karst of the Greenbrier Valley in West Virginia. Zug, (Switzerland) Springer International Publishing, Chapter 2: 9-20. 